\title{
HUBUNGAN KECERDASAN SPIRITUAL (SQ) DENGAN HASIL BELAJAR BAHASA INDONESIA
}

\author{
Lili Hasmi \\ STKIP Yayasan Abdi Pendidikan \\ Lilihasmi1965@gmail.com
}

Submit, 17-10-2019 Accepted, 25-12-2019 Publish, 25-12-2019

\begin{abstract}
ABSTRAK
Tujuan penelitian ini adalah untuk mendeskripsikan kecerdasan spiritual (SQ) dengan hasil belajar Bahasa Indonesia siswa SMP N 5 Kota Bukittinggi. Metode yang digunakan adalah metode korelasi. Hasil penelitian menemukan bahwa terdapat hubungan yang signifikan antara kecerdasan spiritual (SQ) dengan hasil belajar bahasa Indonesia karena hasil pengujian hipotesis membuktikan bahwa $t_{\text {hitung }}$ lebih besar dari $t_{\text {tabel }}$ yaitu, 2,182> 1,708. Simpulan, terdapat korelasi yang signifikan antara kecerdasan spiritual dengan prestasi belajar Bahasa Indonesia.
\end{abstract}

Kata Kunci: Kecerdasan Spiritual (SQ), Hasil Belajar

\section{ABSTRACT}

The purpose of this study was to describe Spiritual Question outcomes of Indonesian students in class VII SMP N 5 Kota Bukittinggi. The method used was the correlation method. The results found that there was a significant relationship between Spiritual Question and Indonesian language learning outcomes because the results of hypothesis testing proved that tcount was greater than ttable namely, 2.182> 1.708. Thus the results of this study there is a significant relationship between Spiritual Question with Indonesian language learning outcomes

Keywords: Spiritual Question, Learning Achievement

\section{PENDAHULUAN}

Kecerdasan spiritual $(S Q)$ merupakan landasan yang diperlukan untuk memfungsikan $I Q$ dan $E Q$ secara efektif, bahkan $S Q$ disebut the ultimate intelligence atau kecerdasan tertinggi. Orang yang memiliki kecerdasan spiritual yang tinggi biasanya memiliki dedikasi kerja yang tulus dan jauh dari kepentingan pribadi (egoisme), apalagi bertindak dzalim kepada orang lain. Untuk mendapatkan hasil yang optimal dari proses belajar, lembaga pendidikan sekolah dapat melaksanakan juga pembinaan spiritual pada siswa, pembinaan spiritual dimaksudkan sebagai jalan atau cara untuk menyikapi spiritual manusia melalui latihan-latihan yang bersifat fisik dan nonfisik. Latihan-latihan tersebut diantaranya melakukan puasa, mendirikan shalat 
dengan baik, berdzikir dan mujahadah dalam menekan hawa nafsu. Contoh kecerdasan spiritual siswa yang baik di dalam pembelajaran seperti memiliki keyakinan dan percaya diri untuk tidak mencontek, mengubah kebiasaan terlambat menjadi tampil terdepan, memiliki gairah atau semangat setiap melakukan tugas pembelajaran. Dari proses pembinaan spiritual ini, maka siswa bukan hanya memperoleh kecerdasan Intelektual $(I Q)$ saja melainkan juga mendapatkan kecerdasan Spiritual $(S Q)$.

Kecerdasan spiritual adalah kemampuan untuk memberi makna ibadah terhadap setiap perilaku dan kegiatan, melalui langkah- langkah dan pemikiran yang bersifat fitrah, menuju manusia yang seutuhnya, dan memiliki pola pemikiran tauhid serta berprinsip "hanya karena Allah" (Ginanjar, 2001). Kecerdasan spiritual adalah kecerdasan jiwa yang dapat membantu seseorang membangun dirinya secara utuh. Kecerdasan spiritual tidak bergantung pada budaya atau nilai. Tidak mengikuti nilainilai yang ada, tetapi menciptakan kemungkinan untuk memiliki nilai-nilai sendiri (Baharuddin \& Zakaria, 2018).

Karakteristik orang-orang yang cerdas spiritual adalah berbuat baik, menolong, berempati, memaafkan, memiliki kebahagiaan, memiliki sense of humor yang baik, dan merasa memikul misi mulia dalam hidupnya. menyatakan orang yang cerdas spiritual harus memiliki ciri-ciri seperti kesadaran diri, spontanitas, termotivasi secara internal, kasih sayang (rasa berkomunitas, rasa mengikuti aliran kehidupan), menghargai keragaman, mandiri dan sebagainya

Aspek dari kecerdasan spiritual sebagai berikut: Pertama, kesadaran diri.; kedua, kemampuan untuk melalakukan perubahan yang lebih baik, ketiga, perenungan akan setiap perbuatan; keempat, kemamapuan untuk menghancurkan rintangan; kelima, kemampuan untuk menentukan langkah dan pemberia keputusan dengan bijak, keenam, kualitas dalam hidup dan makna hidup, ketujuh, menghormati pendapat atau pilihan orang lain. Oleh karena itu kemampuan untuk melihat sesuatu secara jernih dan objektif harus didahului oleh kemampuan mengenali faktor-faktor yang mempengaruhinya itu, caranya dengan mengembalikan manusia pada fitrah hatinya atau "God-Spot". Sehingga manusia akan mampu melihat dengan "Mata Hati", mampu memilih dengan tepat, memprioritaskan dengan benar (Ginanjar, 2001).

Faktor yang mempengaruhi kecerdasan spiritual yaitu :Sel saraf otak Otak menjadi jembatan antara kehidupan bathin dan lahiriah kita. Ia mampu menjalankan 
semua ini karena bersifat kompleks, luwes, adaptif dan mampu mengorganisasikan diri. Menurut penelitian yang dilakukan pada era 1990-an dengan menggunakan WEG (Magneto - Encephalo - Graphy) membuktikan bahwa osilasi sel saraf otak pada rentang $40 \mathrm{~Hz}$ merupakan basis bagi kecerdasan spiritual (Zohor dan Marshall, 2007:35$83)$.

Penelitian ini relevan dengan yang dilakukan oleh Ashshidieqy (2018) terdapat hubungan kecerdasan spritual terhadap pretasi belajar siswa. Santika (2018) terdapat hubungan kecerdasan spritual siswa dengan prestasi belajar siswa. Chandra (2017) terdapat Hubungan antara Kecerdasan Emosional dengan Motivasi Belajar pada Mahasiswa. Hakim (2018) terdapat hubungan antara kecerdasan emosional dan motivasi belajar matematika Sahabuddin (2015) terdapat hubungan komunikasi belajar mengajar terhadap hasil belajar peserta didik. Namun, dalam penelitian ini kecerdasan spiritual difokuskan pada hasil belajar Bahasa Indonesia, kecerdasan spiritual adalah kemampuan untuk memberi makna ibadah terhadap setiap perilaku dan kegiatan, melalui langkah- langkah dan pemikiran yang bersifat fitrah, menuju manusia yang seutuhnya, dan memiliki pola pemikiran tauhid serta berprinsip "hanya karena Allah.

\section{METODE PENELITIAN}

Penelitian ini termasuk ke dalam jenis penelitian kuantitatif dengan menggunakan metode korelasi. Populasi dalam penelitian ini siswa kelas VII SMP N 5 Kota Bukittinggi yang berjumlah 130 orang. Cara penarikan sampel dengan menggunakan teknik cluster random sampling yang berjumlah 27 orang. Adapun instrument yang digunakan dalam penelitian ini adalah angket yang diedarkan kepada siswa yang menjadi sampel penelitian. Angket ini berisi pertanyaan mengenai kecerdasan spiritual (SQ) siswa. Skor yang diberikan disusun berdasarkan penilaian yang diberi rentangan nilai yang rendah sampai yang tinggi dengan menggunakan Skala Likert. Dimana prosedurnya adalah angket diberikan kepada siswa berjumlah 27 orang yang sudah di tetapkan sebagai sampel penelitian, dari hasil angket yang di isi siswa tersebut kita akan menganalisia data sesuai dengan prosedur yang sudah ditetapkan sebelumnya.

Angket yang digunakan berdasarkan Skala Likert yang berisi sejumlah pertanyaan yang menyatakan objek yang hendak diungkap. Penskoran atas angket Skala 
Likert yang digunakan dalam penelitian ini merujuk pada lima alternatif jawaban yaitu: Selalu (SL), Sering (SR), Kadang-kadang (KD), Jarang (JR), Sangat Tidak Pernah (TP). Masing-masing diberi bobot 1 sampai 5 untuk jawaban positif dan 5 sampai dengan 1 untuk jawaban negatif. Instrument dalam penelitian ini sebelum diberikan kepada responden sesungguhnya terlebih dahulu diuji cobakan, dengan tujuan untuk memperbaiki dan menyempurnakan angket yang akan digunakan untuk pengambilan data yang sebenarnya.

\section{HASIL PENELITIAN}

\section{Nilai Kecerdasan Spritual (SQ)}

Kecerdasan spiritual (SQ) merupakan tingkat kecerdasan tertinggi karena bernotaben terhadap kecerdasan hati dimana manusia sebagai makhluk ciptaan tuhan yang sempurna karena pembeda manusia dengan makhluk ciptaan lain ialah hati sebagai petunjuk rohaniah dalam pembeda yang hak dan bathil mapun yang baik dan benar dan itu semua bersumber dari hati (Qalbu), (a) nilai kecerdasan spiritual (SQ) dan (b) rata-rata nilai kecerdasan spiritual (SQ).

Tabel 1

Nilai Kecerdasan Spiritual Siswa

\begin{tabular}{|c|c|c|c|c|}
\hline No & Kode Sampel & Jumlah Skor & Nilai & Kualifikasi \\
\hline 1 & 01 & 148 & 82 & Baik \\
\hline 2 & 02 & 151 & 84 & Baik \\
\hline 3 & 03 & 159 & 88 & Baik Sekali \\
\hline 4 & 04 & 140 & 78 & Baik \\
\hline 5 & 05 & 154 & 86 & Baik Sekali \\
\hline 6 & 06 & 159 & 88 & Baik sekali \\
\hline 7 & 07 & 144 & 80 & Baik \\
\hline 8 & 08 & 147 & 82 & Baik \\
\hline 9 & 09 & 158 & 88 & Baik Sekali \\
\hline 10 & 10 & 154 & 86 & Baik Sekali \\
\hline 11 & 11 & 134 & 74 & Lebih dari Cukup \\
\hline 12 & 12 & 149 & 83 & Baik \\
\hline 13 & 13 & 150 & 83 & Baik \\
\hline 14 & 14 & 158 & 88 & Baik Sekali \\
\hline 15 & 15 & 159 & 88 & Baik Sekali \\
\hline 16 & 16 & 146 & 81 & Baik \\
\hline 17 & 17 & 162 & 90 & Baik Sekali \\
\hline 18 & 18 & 153 & 85 & Baik \\
\hline 19 & 19 & 135 & 75 & Lebih dari Cukup \\
\hline
\end{tabular}




\begin{tabular}{llllc}
\hline 20 & 20 & 139 & 77 & Baik \\
\hline 21 & 21 & 159 & 88 & Baik Sekali \\
\hline 22 & 22 & 137 & 76 & Baik \\
\hline 23 & 23 & 158 & 88 & Baik Sekali \\
\hline 24 & 24 & 152 & 84 & Baik \\
\hline 25 & 25 & 160 & 89 & Baik Sekali \\
\hline 26 & 26 & 159 & 88 & Baik Sekali \\
\hline 27 & 27 & 152 & 84 & Baik \\
\hline \multicolumn{7}{r}{ Jumlah } & $\mathbf{4 0 7 6}$ & $\mathbf{2 2 6 3}$ & Baik \\
\hline & Rata-rata & & &
\end{tabular}

Berdasarkan tabel di atas, terlihat bahwa perolehan nilai tertinggi adalah 90 dan nilai terendah adalah 74. Setelah skor dan nilai kecerdasan spiritual didapat selanjutnya skor dan nilai tersebut diklasifikasikan dengan perhitungan persentase skala 10. Untuk lebih jelasnya terlihat pada tabel berikut ini:

Tabel 2

Klasifikasi Kecerdasan Spiritual siswa

\begin{tabular}{ccccc}
\hline No & Tingkat Penguasaan & Kualifikasi & Frekuensi & Persentase \\
\hline 1 & $96-100 \%$ & Sempurna & & \\
\hline 2 & $86-95 \%$ & Baik Sekali & 12 & $44,44 \%$ \\
\hline 3 & $76-85 \%$ & Baik & 13 & $48,15 \%$ \\
\hline 4 & $66-75 \%$ i & Lebih dari Cukup & 2 & $7,41 \%$ \\
\hline 5 & $56-65 \%$ & Cukup & \\
\hline 6 & $46-55 \%$ & Hampir Cukup & \\
\hline 7 & $36-45 \%$ & Kurang & \\
\hline 8 & $26-35 \%$ & Kurang Sekali & \\
\hline 9 & $16-25 \%$ & Buruk & \\
\hline 10 & $0-15 \%$ & Buruk Sekali & \\
\hline
\end{tabular}

Berasarkan tabel di atas dapat disimpulkan bahwa kualifikasi baik sekali diperoleh 12 orang dengan presentase 44,44\%, kualifikasi baik diperoleh 13 orang dengan presentase 48,15\%, kualifikasi lebih dari cukup diperoleh 2 orang dengan presentase $7,41 \%$, kualifikasi, nilai rata-rata nilai kecerdasan spiritual siswa adalah 84 dengan kualifikasi baik.

\section{Rata-rata Nilai Kecerdasan Spiritual (SQ) Siswa}

Setelah didapatkan nilai kecerdasan spiritual (SQ)r siawa seperti yang tertera di 
atas, selanjutnya adalah mencari nilai rata-rata dengan menggunakan rumus mean. Berikut ini dapat dilihat (1) rata-rata nilai kecerdasan spiritual

Tabel 3

Distribusi Nilai Kecerdasan Spiritual Siswa

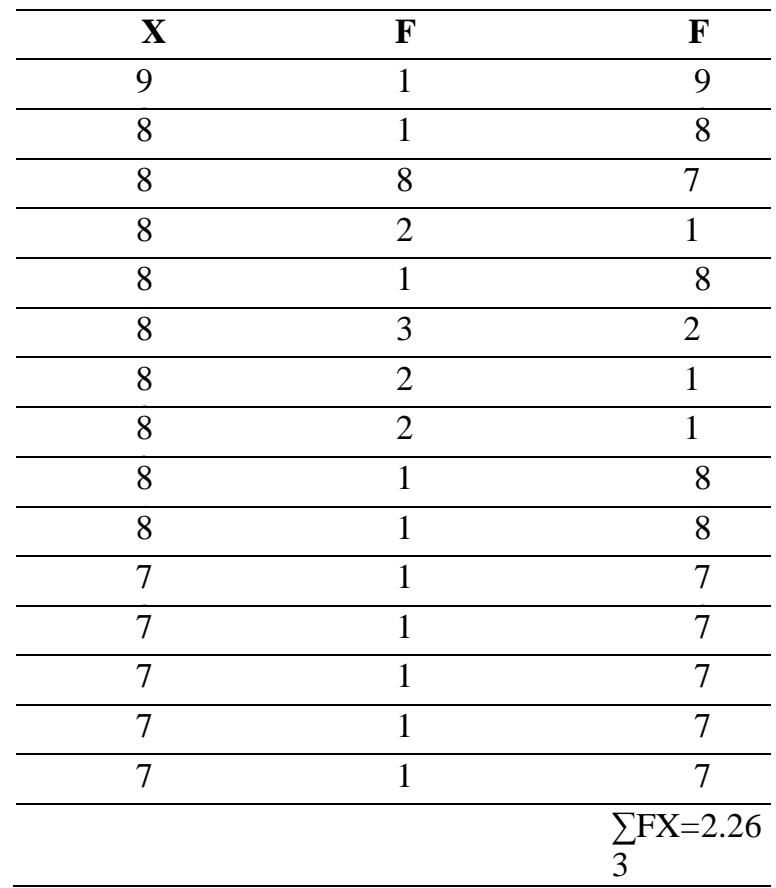

Setelah data dimasukkan ke dalam tabel distribusi, selanjutnya data tersebut dimasukkan ke dalam rumus berikut:

$$
\begin{aligned}
& M=\sum F X \\
& N \\
&=\frac{2268}{27} \\
& M=84
\end{aligned}
$$

Berdasarkan hasil dari rumus di atas, terlihat bahwa nilai rata-rata nilai kecerdasan spiritual siswa adalah 84 dengan kualifikasi baik

\section{Nilai Hasil Belajar Siswa}

Skor yang akan diubah menjadi nilai adalah skor mentah hasil belajar. Adapun nilai masing-masing sampel untuk hasil belajar dapat dilihat pada tabel 4 berikut ini. 
Tabel 4

Hasil Belajar Bahasa Indonesia Siswa

\begin{tabular}{|c|c|c|c|}
\hline No & Kode Sampel & Nilai & Kualifikasi \\
\hline & 01 & 85 & Baik \\
\hline 2 & 02 & 75 & Lebih dari Cukup \\
\hline 3 & 03 & 87 & Baik Sekali \\
\hline 4 & 04 & 80 & Baik \\
\hline 5 & 05 & 83 & Baik \\
\hline 6 & 06 & 87 & Baik Sekali \\
\hline 7 & 07 & 80 & Baik \\
\hline 8 & 08 & 83 & Baik \\
\hline 9 & 09 & 85 & Baik \\
\hline 10 & 10 & 87 & Baik Sekali \\
\hline 11 & 11 & 79 & Baik \\
\hline 12 & 12 & 87 & Baik Sekali \\
\hline 13 & 13 & 86 & Baik Sekali \\
\hline 14 & 14 & 81 & Baik \\
\hline 15 & 15 & 86 & Baik Sekali \\
\hline 16 & 16 & 88 & Baik Sekali \\
\hline 17 & 17 & 89 & Baik Sekali \\
\hline 18 & 18 & 81 & Baik \\
\hline 19 & 19 & 87 & Baik Sekali \\
\hline 20 & 20 & 81 & Baik \\
\hline 21 & 21 & 87 & Baik Sekali \\
\hline 22 & 22 & 80 & Baik \\
\hline 23 & 23 & 83 & Baik \\
\hline 24 & 24 & 81 & Baik \\
\hline 25 & 25 & 85 & Baik \\
\hline 26 & 26 & 84 & Baik \\
\hline 27 & 27 & 87 & Baik Sekali \\
\hline \multicolumn{2}{|r|}{ JUMLAH } & 2264 & Baik \\
\hline & ATA-RATA & & \\
\hline
\end{tabular}

Berdasarkan tabel 4 terlihat perolehan nilai hasil belajar. Perolehan nilai tertinggi adalah 89 sedangkan perolehan nilai terendah adalah 75. Diuraikan secara lengkap sebagai berikut: nilai 89 diperoleh 1 orang, nilai 85 diperoleh 1 orang, nilai 87 diperoleh 7 orang, nilai 86 diperoleh 2 orang, nilai 85 diperoleh 3 orang, nilai 84 diperoleh 1 orang, nilai 83 diperoleh 3 orang, nilai 81 diperoleh 4 orang, nilai 80 diperoleh 3 orang, nilai 79 diperoleh 1 orang, nilai 75 diperoleh 1 orang, nilai 69 diperoleh 2 orang, nilai 68 diperoleh 2 orang, nilai 60 diperoleh 1 orang. Untuk lebih jelasnya nilai persentase kreativitas belajar siswa sebagai berikut. 
Tabel 5

Klasifikasi Persentase Hasil Belajar Bahasa Indonesia Siswa

\begin{tabular}{ccccc}
\hline No & Tingkat Penguasaan & Kualifikasi & Frekuensi & Persentase \\
\hline 1 & $96-100 \%$ & Sempurna & & \\
\hline 2 & $86-95 \%$ & Baik Sekali & 11 & $40.75 \%$ \\
\hline 3 & $76-85 \%$ & Baik & 15 & $55.55 \%$ \\
\hline 4 & $66-75 \%$ & Lebih dari Cukup & 1 & $3.70 \%$ \\
\hline 5 & $56-65 \%$ & Cukup & \\
\hline 6 & $46-55 \%$ & Hampir Cukup & \\
\hline 7 & $36-45 \%$ & Kurang & \\
\hline 8 & $26-35 \%$ & Kurang Sekali & \\
\hline 9 & $16-25 \%$ & Buruk & & \\
\hline 10 & $0-15 \%$ & Buruk Sekali & 27 & \\
\hline
\end{tabular}

Berdasarkan tabel 5 dapat disimpulkan bahwa kualifikasi baik sekali diperoleh 11 orang dengan presentase 40.75\%, kualifikasi baik diperoleh 15 orang dengan presentase $55.55 \%$, kualifikasi lebih dari cukup diperoleh 1 orang dengan presentase $3.70 \%$.

\section{Rata-rata Hasil Belajar}

Setelah didapatkan perolehan jumlah nilai ujian semester 1 Bahasa Indonesia siswa, selanjutnya adalah mencari nilai rata-rata dengan menggunakan rumus mean Berikut ini dapat dilihat nilai ujian semester 1 Bahasa Indonesia.

\section{Tabel 6}

Distribusi hasil Belajar Bahasa Indonesia Siswa

\begin{tabular}{ccc}
\hline $\mathbf{X}$ & $\mathbf{F}$ & $\mathbf{X F}$ \\
\hline 89 & 1 & 89 \\
\hline 88 & 1 & 88 \\
\hline 87 & 7 & 609 \\
\hline 86 & 2 & 172 \\
\hline 85 & 3 & 255 \\
\hline 84 & 1 & 84 \\
\hline 83 & 3 & 249 \\
\hline 81 & 4 & 324 \\
\hline 80 & 3 & 240 \\
\hline 79 & 1 & 79 \\
\hline 75 & 1 & 75 \\
\hline & $\sum \mathbf{N}=\mathbf{2 7}$ & $\sum \mathrm{FX}=2264$ \\
\hline
\end{tabular}


Setelah data dimasukkan ke dalam tabel distribusi, selanjutnya data tersebut dimasukkan ke dalam rumus berikut:

$$
\begin{gathered}
\mathrm{M}=\sum \mathrm{FX} \\
=\frac{\mathrm{N}}{2264} \\
\mathbf{M}=\mathbf{8 4}
\end{gathered}
$$

Berdasarkan hasil dari rumus di atas, terlihat bahwa nilai rata-rata nilai kecerdasan spiritual siswa adalah 84 dengan kualifikasi baik

\section{Hubungan Kecerdasan Spiritual dengan Hasil Belajar Siswa}

Untuk mencari tingkat hubungan kecerdasan spiritual dengan hasil belajar Bahasa Indonesia siswa digunaan rumus product moment. Data nilai Kecerdasan Spiritual sebagai variabel $\mathrm{X}$ dan nilai ujian semester 1 Bahasa Indonesia sebagai variabel Y. Setelah diperoleh $\mathrm{t}$ dari rumus tersebut, dilanjutkan dengan membandingkan nilai $t_{\text {hitung }}$ dengan $t_{\text {tabel }}$ pada taraf signifikan 0,05 dengan derajat kebebasan $n-2(27-$ 2).

Tabel 7

Hubungan Kecerdesan Spiritual dengan Hasil Belajar

\begin{tabular}{cccc}
\hline $\mathbf{R}$ & $\begin{array}{c}\text { Thitun } \\
\mathbf{g}\end{array}$ & $\mathbf{N - 2}$ & Ttabel \\
\cline { 3 - 4 } & & & $\mathbf{0 , 0 5}$ \\
\hline 0,400 & 2,182 & 25 & 1,708 \\
\hline
\end{tabular}

Pengujian hipotesis berdasarkan $r_{\text {hitung }}$ 0,400 diperoleh $t_{a b e l} 2,182$ dengan derajat kebebasan N-2 $(27-2=25)$, dan taraf signifikan 0,05. Hipotesis diterima jika $t_{\text {hitung }}>t_{\text {tabel. }}$. Dengan demikian $H_{1}$ diterima karena hasil pengujian membuktikan bahwa $\mathrm{t}_{\text {hitung }}$ lebih besar dari $\mathrm{t}_{\text {tabel }}$ yaitu 2,182> 1,708. Dapat disimpulkan bahwa terdapat korelasi yang signifikan antara kecerdasan spiritual dengan prestasi belajar Bahasa Indonesia siswa kelas VII SMP Negeri 5 Kota Bukittinggi.

\section{PEMBAHASAN}

Kecerdasan spiritual merupakan faktor yang penting dalam proses belajar mengajar, dan perlu diperhatikan untuk perkembangan kecerdasan dan potensi diri pada 
siswa. Bahasa Indonesia adalah mata pelajaran wajib dalam dunia pendidikan sebagai pembelajaran akademis dan juga bahasa pemersatu bangsa. Berdasarkan pendapat Ginanjar (2001) kecerdasan spiritual adalah kemampuan untuk memberi makna ibadah terhadap setiap perilaku dan kegiatan, melalui langkah- langkah dan pemikiran yang bersifat fitrah, menuju manusia yang seutuhnya, dan memiliki pola pemikiran tauhid serta berprinsip "hanya karena Allah". Sedangkan kecerdasan spritual siswa di lihat dengan hasil belajarnya yang kita ambil dari nilai semesternya dan diadakan uji hipotesisnya. Menurut Djamarah (Febriani, 2017) hasil belajar merupakan tolak ukur keberhasilan dalam proses pembelajaran yang memberikan gambaran mengenai sejauh mana pemahaman siswa akan pengetahuan yang diperolehnya disekolah. Sekolah menjadi lembaga pendidikan yang memiliki andil penting dalam kegiatan belajar mengajar untuk mengarahkan pada penguasaan cara belajar.

Pengujian hipotesis berdasarkan $r_{\text {hitung }}$ 0,400 diperoleh $t_{\text {thitung }} 2,182$ dengan derajat kebebasan N-2 $(27-2=25)$, dan taraf signifikan 0,05. Hipotesis diterima jika $t_{\text {hitung }}>t_{\text {tabel }}$. Dengan demikian $H_{1}$ diterima karena hasil pengujian membuktikan bahwa $t_{\text {hitung }}$ lebih besar dari $t_{\text {tabel }}$ yaitu 2,182> 1,708. Dapat disimpulkan bahwa terdapat korelasi yang signifikan antara kecerdasan spiritual dengan prestasi belajar Bahasa Indonesia siswa kelas VII SMP N 5 Kota Bukittinggi.

\section{SIMPULAN}

Kecerdasan spiritual memberikan pengaruh besar terhadap hasil belajar bahasa indonesia, secara keseluruhan terdapat hubungan yang signifikan antara kecerdasan spiritual (SQ) dengan hasil belajar bahasa indonesia siswa kelas VII SMP N 5 Kota Bukittinggi.

\section{DAFTAR PUSTAKA}

Ashshidieqy, H. (2018). Hubungan Kecerdasan Spiritual terhadap Prestasi Belajar Siswa. 70-76.

Baharuddin, \& Rahmatia, Z. (2018). Pengaruh Kecerdasan Spiritual Terhadap Peningkatan Kinerja Guru di SMA Negeri 3 Takalar. Jurnal ilmu ushludin. 2(1)

Chandra, A. (2017). Hubungan antara Kecerdasan Emosional dengan Motivasi Belajar pada Mahasiswa. 1-10 
Febriani, P.,S \& Alit., S. (2017). Dampak Cara Belajar dan Aktivitas belajar dalam Meningkatkan Prestasi Belajar Siswa Sekolah Menengah Kejuruan. Jurnal Manajerial, 2(2)

Ginanjar, Agustin, A . (2001). Rahasia Sukses Membangun Kecerdasan Emosi dan Spiritual ESQ. Jakarta: Arga.

Hakim, A.,R. (2018). Hubungan antara Kecerdasan emosional dan Motivasi Belajar Matematika SMP. 165-176

Sahabuddin, C. (2015). Hubungan Komunikasi Belajar Mengajar terhadap Hasil Belajar Peserta Didik di SMK N 1 Kabupaten Majeneh. 17-30.

Santika, D.,N. (2018). Hubungan Kecerdasan Spiritual Siswa dengan Prestasi Belajar Siswa Pai. 190-199. 